\title{
TANTANGAN PENGEMBANGAN PADI DIKABUPATEN KEPULAUAN MENTAWAI
}

\section{THE CHALLENGE OF RICE DEVELOPMENT IN THE MENTAWAI ISLAND DISTRICT}

\author{
Rafnel Azhari, Bujang Rusman, Musliar Kasim, Auzar Syarif, Reflinaldon, \\ Syafrimen Yasin, Afrizal Zainal, dan Junaidi \\ Dosen Fakulas Pertanian, Universitas Andalas \\ Email: azharirafnel@yahoo.com
}

\begin{abstract}
This study aims to identify the problems and develop rice agribusiness in Mentawai Islands from upstream to downstream and formulate appropriate policy recommendations to be implemented. The research location determined by purposive namely in the village Makalo and Malakopa District of South Pagai, Sikakap subdistrict Taikako Village, Village Saumanganya District of North Pagai, Bosua Village and Village Beriulou District of South Sipora, Village Rogdog and Madobag District of South Siberut. Respondents in this study were 30 farmers. Respondents farmers selected by simple random sampling method. The results showed that the majority of rice paddies new openings in six districts consist of peatlands with a depth varying from 0.4- > 2.0 meter, fields new openings that have been implemented in the Mentawai Islands in general can not be expected to result in maximum productivity due to problems of land suitability diverse. Farmers also do not take action appropriate technical culture starting from land preparation, seed selection, weeding, fertilizing and water management. Behaviorally agriculture, farmers in Mentawai Islands is not a society that blends with the culture of rice fields, it is because basically their agricultural base is dry land agriculture with farming patterns. This will certainly give a great challenge and not easy for the cultivation of rice in the Mentawai Islands.
\end{abstract}

Keywords:challenge, rice agribusiness, cultivation of rice

\section{PENDAHULUAN}

Kabupaten Kepulauan Mentawai merupakan kabupaten kepulauan di Provinsi Sumatera Barat yang terletak memanjang dibagian paling barat pulau Sumatera dan dikelilingi oleh Samudera Hindia(BPS, 2016). Sektor pertanian di Kepulauan Mentawai masih merupakan sektor yang menyerap tenaga kerja terbanyak dibandingkan sektor - sektor lain. Sebanyak $86,53 \%$ penduduk pada tahun 2015 bekerja dan melakukan kegiatan di sektor pertanian. Pembangunan sektor pertanian dilakukan dengan memanfaatkan sumber daya alam, tenaga dan teknologi pertanian yang masih konvensional. Dilihat dari kontribusinya terhadap Produk Domestik Regional Bruto (PDRB) sektor pertanian masih 
tercatat sebagai penyumbang terbesar $(56,35 \%)$ dalam pembentukan PDRB Kabupaten Kepulauan Mentawai (BPS, 2016).

Salah satu program dinas pertanian, peternakan dan perkebunan kabupaten kepulauan Mentawai adalah peningkatan produksi pertanian, perkebunan, peternakan dan agroindustri berbasis kawasan (sentra produksi). Program pemerintah daerah yang sangat strategis ini ditujukan untuk peningkatan ketahanan pangan dalam upaya mempercepat terwujudnya kedaulatan pangan, yakni kemandirian dalam pemenuhan kebutuhan pangan di kabupaten kepulauan Mentawai (Dinas Pertanian, Peternakan dan Perkebunan Kabupaten Kepulauan Mentawai, 2015).

Salah satu bentuk kegiatan untuk mencapai program peningkatan pangan tersebut adalah melalui ekstensifikasi pertanian dengan pembukaan lahan pertanian berupa mencetak sawah baru seluas 600 hektar yang telah dilakukan sejak tahun 2012 sampai 2014 di beberapa wilayah seperti pada (a) Kecamatan Pagai Selatan di Desa Makalo dan Desa Malakopa, (b) Kecamatan Pagai Utara di Desa Saumanganya dan Dusun Pasapuat, (c) Kecamatan Sikakap di Desa Taikako, (d) Kecamatan Sipora Selatan di Desa Bosua dan Desa Beriulou, (e) Kecamatan Sipora Utara di Desa Tuapejat, dan (f) Kecamatan Siberut Selatan di Desa Madobag yang berada pada Dusun Madobag dan Dusun Rokdog (Dinas Pertanian, Peternakan dan Perkebunan Kabupaten Kepulauan Mentawai, 2015).

Dari luasan tersebut, produktivitas padi yang dihasilkan masih sangat rendah. Berdasarkan identifikasi pemerintah daerah Kabupaten Kepulauan Mentawai, disebutkan bahwa sebagian besar mengalami gagal panen yang disebabkan oleh banyak faktor diantaranya serangan hama dan penyakit, perilaku budidaya petani, jenis tanah dan gejala lain pada saat tanaman masih muda (Dinas Pertanian, Peternakan dan Perkebunan Kabupaten Kepulauan Mentawai, 2015).

Permasalahan budidaya tanaman padi di lokasi tersebut diatas seperti yang digambarkan oleh Pemda Kabupaten Kepulauan Mentawai adalah produktivitas masih rendah dan bahkan sebagian mengalami kegagalan. Beberapa faktor penyebabnya diduga antara lain oleh: (1) kesuburan tanah dan manajemen lahan, (2) serangan hama penyakit, (3) budidaya tanaman padi, (4) perilaku petani, dan (5) penyuluhan pertanian (Dinas Pertanian, Peternakan dan Perkebunan Kabupaten Kepulauan Mentawai, 2015). Walaupun pemerintah daerah Kepulauan Mentawai sudah berupaya untuk memberikan bantuan dan pendampingan, tetapi fakta di lapangan menunjukkan bahwa produktivitas padi sawah petani masih rendah (Dinas Pertanian, Peternakan dan Perkebunan Kabupaten Kepulauan Mentawai, 2015). Permasalahan ini tentu akan menghambat pencapaian ketahanan pangan di Kabupaten Kepulauan Mentawai.

Oleh karena itu, dilakukan penelitian yang di fokuskan pada upaya mencari dan mengidentifikasi permasalahan agribisnis pengembangan padi dari

42 | Rafnel Azhari, dkk; Tantangan Pengembangan Padi di Kabupaten ... 
hulu sampai hilir serta merumuskan rekomendasi kebijakan yang tepat untuk diimplementasikan oleh Pemda Kabupaten Kepulauan Mentawai. Dengan demikian, tujuan dari penelitian ini adalah untuk mempelajari dan mengidentifikasi permasalahan agribisnis tanaman padi di Kabupaten Kepulauan Mentawai dari aspek teknis budidaya sampai sosial ekonomi. Secara rinci, tujuan penelitian ini adalah untuk mengidentifikasi permasalahan dan tantangan budidaya padi di lahan sawah bukaan baru maupun rehab dan menyusun rekomendasi perbaikan kebijakan dan teknis budidaya tanaman padi di Kabupaten Kepulauan Mentawai

\section{METODE PENELITIAN}

\section{Penentuan Lokasi Penelitian}

Lokasi penelitian ditentukan secara purposive yaitu di Desa Makalo dan Malakopa Kecamatan Pagai Selatan, Desa Taikako Kecamatan Sikakap, Desa Saumanganya Kecamatan Pagai Utara, Desa Bosua dan Desa Beriulou Kecamatan Sipora Selatan, Dusun Rogdog dan Madobag Kecamatan Siberut Selatan. Dengan pertimbangan bahwa daerah tersebut merupakan lokasi pencetakan sawah baru yang telah ditanam dan bahkan disebagian lokasi sudah pernah dipanen.

\section{Penentuan Responden}

Responden dalam penelitian ini berjumlah 30 orang petani, dan informan kunci dari Dinas Pertanian Kabupaten Mentawai 3 orang serta penyuluh 5 orang. Responden petani dipilih dengan metode Simple random sampling. Jumlah petani yang mengikuti program pembukaan sawah baru dilokasi penelitian adalah 60 orang petani. Dalam penelitian ini, peneliti hanya mengambil $50 \%$ jumlah petani, yakni 30 orang yang diambil secara acak menggunakan metode acak sederhana, alasannya agar data yang diperoleh lebih faktual dan petani pemilik sawah dikategorikan sama. Menurut Surachmad (1990), apabila populasi cukup homogen terhadap populasi dibawah 100 dapat dipergunakan sampel sebesar $50 \%$.

Kepada informan kunci dilakukan wawancara mendalam. Informan kunci adalah orang yang dimanfaatkan untuk memberikan informasi, jadi informan kunci adalah orang yang memiliki banyak pengalaman dan pengetahuan tentang permasalahan yang akan diteliti sehingga mampu memberikan informasi yang dibutuhkan (Koenjtaningrat, 1985). Penelitian ini menggunakan informan kunci dari dinas pertanian dan penyuluh untuk memberikan gambaran tentang budidaya padi di Kabupaten Mentawai yang ditinjau dari : aspek budidaya sampai pemasaran, perilaku petani dan kondisi kelembagaan petani yang ada. 


\section{Metode Analisis Data}

Pengumpulan data dilakukan dengan metoda survey untuk menggali data primer, dilakukan dengan cara diskusi dan wawancara dengan petani, ketua kelompok tani dan penyuluh pertanian di setiap lokasi kajian di Kabupaten Kepulauan Mentawai. Data sekunder dikumpulkan dari dinas pertanian Kabupaten Mentawai dan Badan Pusat Statistik. Data sekunder yang diperoleh dalam penelitian ini adalah:

1. Kabupaten Kepulauan Mentawai dalam Angka tahun 2015

2. Produk Domestik Regional Bruto Kabupaten Kepulauan Mentawai Menurut Lapangan Usaha tahun 2011-2015

3. Sensus Pertanian tahun 2013

Laporan data luas sawah dan realisasi luas tanam dinas Pertanian kabupaten Kepualuan Mentawai, 2015

Hasil pengamatan lapangan selanjutnya dianalisis secara kualitatif dan didiskusikan oleh tim interdisiplin berdasarkan latar belakang akademik dan pengalaman dalam bidang tanah dan manajemen lahan, budidaya, panen dan pasca panen, serta aspek sosial ekonomi dan perilaku petani.

\section{HASIL DAN PEMBAHASAN}

\section{Tanah dan Manajemen Lahan}

\section{Kecamatan Sipora Selatan}

Lokasi cetak sawah bukaan baru di Kecamatan Sipora terletak di dua desa, yakni desa Beliulou dan desa Bosua. Lokasi sawah bukaan baru di Desa Beliulou merupakan daerah dataran depresi yang berada diantara beting pantai dengan daerah perbukitan. Luas sawah bukaan baru di Desa Beriukou adalah 32 hektar yang dibuka sejak tahun 2014. Berdasarkan kondisi fisiografinya, jenis tanah yang terbentuk adalah tanah gambut dangkal dengan kedalaman $<0,4 \mathrm{~m}$ yang telah mengalami subsidensi dengan faktor penghambatnya adalah masalah tata air, sehingga hampir sepanjang tahun tergenang oleh air. $\mathrm{pH}$ tanah di lokasi ini masam. $\mathrm{pH}$ tanah di lokasi ini adalah 5, yang merupakan tergolong tanah masam. Pembukaan sawah baru diluar pulau Jawa banyak dihadapkan pada $\mathrm{pH}$ tanah yang rendah (Prasetyo,2006). Namun demikian lahan di Desa Beriulou ini tetap mempunyai potensi untuk dikembangkan sebagai lahan sawah, karena merupakan daerah dengan dataran depresi yang berada diantar beting pantai dengan daerah perbukitan. 
Berdasarkan pada ketebalan gambut yang mencapai $100 \mathrm{~s} / \mathrm{d} 150 \mathrm{~cm}$, lahan di lokasi ini termasuk sesuai tingkat sedang (S2) untuk padi sawah dan masih bisa ditingkatkan kesesuaiannya menjadi sangat sesuai (S1) bila dilakukan pembuatan saluran drainase dan manajemen lahan (pemupukan, pemeliharaan tanaman padi yang baik). Hal ini sesuai dengan penelitian yang dilakukan oleh Nasrul (2010) yang menyatakan bahwa tipologi lahan gambut dibedakan atas : gambut dangkal $(50-100 \mathrm{~cm})$, tengahan $(100-200 \mathrm{~cm})$, dalam $(200-300 \mathrm{~cm})$, sangat dalam $(>300 \mathrm{~cm})$.

Lokasi sawah cetakan baru di desa Bosua juga merupakan daerah dataran depresi yang berada diantara beting pantai dengan daerah perbukitan dengan luas sawah bukaan baru 15 hektar yang dibuka sejak tahun 2014 . Berdasarkan kondisi fisiografinya, jenis tanah yang terbentuk adalah tanah gambut agak dalam dengan kedalaman $<1 \mathrm{~m}$. Faktor penghambat di lokasi ini adalah masalah tata air, sehingga lahan petani hampir sepanjang tahun tergenang oleh air.

Berdasarkan pada ketebalan gambut, yakni kurang dari 1 meter, lahan di lokasi ini juga termasuk sesuai tingkat sedang (S2) untuk padi sawah dan masih bisa ditingkatkan kesesuaiannya menjadi tingkat sangat sesuai (S1) bila dilakukan pembuatan saluran drainase dan manajemen lahan (pemupukan, pemeliharaan tanaman padi yang baik).

\section{Kecamatan Siberut Selatan}

Lokasi cetak sawah bukaan baru di Kecamatan Siberut Selatan terletak di dua dusun yaitu Madobag dan Rogdok. Lokasi sawah bukaan baru di Desa Madobag merupakan daerah dataran Alluvial yang cukup subur dari sepanjang sungai Siberut dengan luas cetakan baru sekitar 30 hektar dari bekas sawah yang telah ditinggalkan pada tahun 1970, dan dibuka kembali sejak tahun 2014 . Pada saat pembukaan lahan sebagian lahan sudah ditanami Kakao dan Sagu. Setelah dibuka untuk sawah telah dua kali ditanami dengan tanaman padi varitas IR 42 yang bersertifikat. Lahan sawah bukaan baru ini merupakan sawah tadah hujan yang frekuensi penanaman satu kali setahun dan setelah panen di ikuti dengan masa bera dengan hasil 4 ton gabah/ha.

Produktivitas lahannya masih tergolong rendah, karena terkait dengan manajemen lahan yang belum begitu terencana dengan baik, terutama terkait dengan belum adanya pemberian pupuk berimbang, belum dilakukan penyiangan dan pemberantasan hama dan penyakit. Adapun variability kesuburan tanahnya juga masih bervariasi karena lahan sawah bukaan baru ini berasal dari hutan sekunder dan belum adanya saluran drainase untuk mengatur tata air sawah serta pemeliharaan tanaman belum begitu baik. 
Lokasi sawah bukaan baru di Dusun Rogdog merupakan daerah dataran gambut dalam. Secara fisiografi merupakan dataran cekungan yang berada diantara tanggul sungai Siberut dengan daerah perbukitan di sebelah baratnya. Berdasarkan kondisi fisiografinya terjadi genangan sepanjang tahun dan terbentuknya lahan gambut dalam $(>2 \mathrm{~m})$ dengan tingkat pelapukan hemis dengan kondisi tata airnya yang selalu tergenang sepanjang tahun dengan kedalaman gambut mencapai 2 sampai 3 meter yang sebelumnya merupakan hutan primer alami, sehingga tergolong kedalam lahan yang tidak sesuai permanen (N2) untuk dikembangkan menjadi lahan sawah. Hal ini diperkuat dengan fakta lapangan bahwa pada saat sekarang lokasi sawah sudah ditutupi oleh semak belukar dan sebagian sudah ditanami dengan pisang, talas dan lainlain.

Sawah cetakan baru ini mulai dibuka sejak tahun 2014 dengan luas sekitar 42 hektar dengan jarak sekitar $4 \mathrm{~km}$ dari dusun Rogdog dan sudah dua kali ditanami padi varietas IR 42 bersertifikat, namun mengalami kegagalan. Masalahnya adalah terkait dengan kedalaman gambut dan manajemen lahan gambut yang pengelolaannya tidak sama dengan lahan sawah tadah hujan (Fahmuddin, 2008).

Masalah manajemen lahan gambut tersebut adalah menyangkut belum sempurnanya pengaturan tata airnya dengan pembuatan saluran primer, saluran tersier dan saluran cacing. Adapun dari aspek evaluasi lahannya, lahan gambut mempunyai $\mathrm{pH}$ tanah rendah dan tingkat kesuburan rendah serta adanya keracunan asam-asam organik dari bahan gambut sehingga untuk pengembangan lahan sangat mempunyai banyak kendala. Hal ini menyebabkan tingkat produktivitas lahan gambut yang rendah sehingga menimbukan produksi padi rendah. Gejala yang ditemui, daun padi mulai menguning pada umur satu bulan dan menguning semuanya pada saat pengisian biji padi, dan hal ini yang menyebabkan produksi gagal total, disamping serangan walang sangit.

Bila dilihat dari aspek pengelolaan lahan gambut oleh petani setempat, ditemukan bahwa para petani belum dibekali pengetahuan tentang karakteristik lahan gambut dan budidaya tanaman padi serta belum adanya demplot-demplot yang dilakukan di lahan gambut. Penanaman padi sawah masih merupakan pekerjaan sampingan bagi petani setempat dan diikuti lagi dengan jarak dari Dusun Rogdog relatif jauh sekitar $4 \mathrm{~km}$ dari dusun mereka.

Berdasarkan masalah di atas, maka lahan ini tidak layak dijadikan lahan sawah tetapi dapat dijadikan lahan pertanian palawija berupa lahan kering setelah dilakukan pembuatan saluran drainase untuk mempercepat proses pelapukan gambut sehingga beberapa tahun ke depan akan terjadi penurunan tebal lapisan gambut.

Berdasarkan kajian yang sudah dilakukan oleh LPPM unand (2014) didesa Muntei Sipora Selatan dilaporkan bahwa tanah gambut di Sipora mempunyai 
reaksi tanah yang masam ( $\mathrm{pH}$ rendah), unsur hara $\mathrm{N}$ dan $\mathrm{P}$ tergolong sedang, $\mathrm{K}$ tergolong rendah. Justru itu untuk perbaikan kesuburan tanah diperlukan pemberian kapur Kalsit sebanyak $500 \mathrm{~kg} /$ ha untuk meningkatkan $\mathrm{pH}$ tanah, dan pemberian pupuk Urea sebanyak $200 \mathrm{~kg} / \mathrm{ha}$, SP-36 sebesar $75 \mathrm{~kg} / \mathrm{ha}$ dan $\mathrm{KCl}$ sebesar $125 \mathrm{~kg} / \mathrm{Ha}$.

\section{Kecamatan Pagai Selatan}

Lokasi cetak sawah bukaan baru di Kecamatan Pagai Selatan, terletak di dua dusun, yaitu Dusun Makalo dan Malakopa. Dusun Makalo memiliki lahan sawah sebagian gambut dengan kedalaman lebih kurang $1 \mathrm{~m}$ dan sebagian adalah tanah mineral (alluvial) yang cukup luas dan berpotensi untuk dikembangkan menjadi lahan sawah. Berdasarkan pengukuran langsung menggunakan $\mathrm{pH}$ tester diperoleh derajat kemasaman tanah $(\mathrm{pH})$ sebesar 6 . Lahan sawah yang cukup baik ini terlihat belum dikelola dengan baik oleh petaninya, terutama dalam penyiangan gulma sehingga tanaman tidak tumbuh optimal menurut potensinya. Irigasi dan drainase juga belum ada sehingga ada yang kering dan ada yang sangat tergenang air.

Lahan sawah Makalo memiliki tingkat kesuburan yang cukup baik, karena sebagian adalah tanah mineral, tetapi karena irigasi dan drainase yang belum baik serta penyiangan yang tidak dilakukan maka pertumbuhan padi menjadi kurang baik, demikian pula pemupukan juga belum dilakukan. Sebagian besar dari lahan ini (tanah mineralnya) telah menjadi sawah yang baik dan sudah ditanami berulang kali.

Dalam hal teknik budidaya, yang diterapkan masyarakat masih belum baik karena, belum ada pemupukan, varietas yang digunakan belum varietas yang sesuai/ toleran untuk lahan gambut, penyiangan gulma juga kurang terlaksana, irigasi dan drainase juga belum baik.

Lahan sawah di Desa Makalo perlu mendapat perhatian dan perbaikan dalam hal:

1. Irigasi dan drainase. Irigasi sangat diperlukan untuk sumber air yang baik dan sekaligus sebagai sumber hara dan mineral bagi tanaman. Kemudian juga diperlukan drainase yang baik untuk mengurangi kadar air yang tinggi dan sekaligus untuk mencuci asam-asam organik yang tinggi pada lahan gambut yang dapat menjadi racun bagi tanaman. Drainase harus dilakukan secara baik agar tidak terjadi subsiden yang drastis atau ekstrim. Oleh karena itu saluran irigasi dan drainase perlu ditata sedemikian rupa agar tidak terjadi pengeringan yang berlebihan. Untuk penurunan kadar air gambut disarankan sekitar $10 \mathrm{~cm}$

2. Varietas, disarankan menggunakan varietas yang sesuai/ toleran untuk lahan gambut. 
3. Dalam hal pemupukan dan pengapuran, perlu dilakukan pemberian dolomit $500 \mathrm{~kg} /$ ha dengan pemupukan $100 \mathrm{~kg} /$ ha (2 kali pemberian) dan TSP $200 \mathrm{~kg} /$ ha serta $\mathrm{KCl} 125 \mathrm{~kg} / \mathrm{ha}$

4. Pembersihan kayu dan tunggul penebangan perlu dilakukan agar tidak tidak terjadi peningkatan asam organik yang meracun dari pelapukan kayu dalam kondisi anaerob pada gambut.

5. Penyiangan tanaman perlu dilakukan sampai umur tanaman 2.5 bulan minimal 2 kali penyiangan

Dusun Malakopa memiliki lahan sawah sebagian gambut dengan kedalaman lebih kurang $1 \mathrm{~m}$ dan sebagian adalah tanah mineral (Alluvial) yang cukup luas sekitar 30 ha yang dapat dikembangkan menjadi lahan sawah yang potensial, $\mathrm{pH}$ tanah 6 ( $\mathrm{pH}$ tester). Lahan sawah yang cukup baik ini sayangnya belum dikelola dengan baik oleh petaninya. Terutama dalam pembentukan petakan dan tidak diratakan sehingga ada yang kering dan ada yang dalam airnya, kemudian penyiangan gulma juga tidak terlaksana sehingga tanaman tidak tumbuh optimal menurut potensinya. Irigasi dan drainase juga belum ada sehingga ada yang kering dan ada yang sangat tergenang.

Lahan sawah Dusun Malakopa memiliki tingkat kesuburan yang dapat diperbaiki dengan pemupukan, karena sebagian adalah tanah mineral, tetapi karena irigasi dan drainase yang belum baik serta penyiangan yang tidak dilakukan maka pertumbuhan padi menjadi kurang baik, demikian pula pemupukan juga belum dilakukan. Sebagian besar dari lahan ini (tanah mineralnya) telah disawahkan juga sebelumnya.

Dalam hal teknik budidaya, yang diterapkan masyarakat masih belum baik karena, belum ada pemupukan, varietas yang digunakan belum varietas yang sesuai/ toleran untuk lahan gambut, penyiangan gulma tidak dilakukan dengan sempurna, irigasi dan drainase juga belum baik.

\section{Kecamatan Pagai Utara}

Lokasi cetak sawah bukaan baru di Kecamatan Pagai Utara terletak di dua dusun yakni, Dusun Saumanganya dan dusun Pasapuat. Di Dusun Saumanganya ada sekitar 30 Ha lahan yang sebelumnya sudah menjadi lahan penanaman Talas kini dijadikan lahan sawah (rehab) dan baru 15 ha yang realisasi tanam padi, dan masih besar luas lahan hutan gambut yang berpotensi untuk dibuka menjadi lahan sawah. Tanah memiliki kedalaman 80-150 cm, kematangan pada $10 \mathrm{~cm}$ lapisan atas Saprik dan lapisan bawah juga masih hemik dan fibrik, tanah mineral pada lapisan bawah adalah inseptisol (alluvial), pH 5.6 ( $\mathrm{pH}$ soil terster), irigasi dan drainase belum ada.

Tingkat kesuburan tanah di lahan sawah di dusun Saumanganya tergolong sedang, hal ini disebabkan tingkat kematangan yang juga masih banyak ada tingkat hemik dan fibrik dan belum adanya irigasi dan drainase 
yang memadai. Namun kesuburannya agak lebih baik karena tanah mineral dilapisan bawahnya tanah alluvial yang bertekstur liat berpasir.

Teknik budidaya yang diterapkan masyarakat masih belum baik karena, belum ada pemupukan, varietas yang digunakan juga belum varietas yang sesuai/ toleran untuk lahan gambut, penyiangan gulma juga kurang terlaksana, irigasi dan drainase belum baik karena lahan ini sebagian adalah bekas lahan tanam Talas maka kayu-kayu besarnya sudah berkurang sedangkan pada lahan bukaan baru masih terdapat kayu-kayu besar dan tunggul-tunggul penebangan juga masih banyak.

Lahan sawah di dusun Saumanganya perlu mendapat perhatian dan perbaikan dalam hal:

1. Dalam hal Irigasi dan drainase. Irigasi sangat diperlukan untuk sumber air yang baik dan sekaligus sebagai sumber hara serta mineral bagi tanaman. Kemudian juga diperlukan drainase yang baik untuk mengurangi kadar air yang tinggi dan sekaligus untuk mencuci asam-asam organik yang tinggi pada lahan gambut yang dapat meracun bagi tanaman. Drainase harus dilakukan secara baik agar tidak terjadi subsiden yang drastis atau ekstrim. Oleh karena itu saluran irigasi dan drainase perlu ditata sedemikian rupa agar tidak terjadi pengeringan yang berlebihan, penurunan kadar air gambut disarankan sekitar $10 \mathrm{~cm}$

2. Varietas, disarankan menggunakan varietas yang sesuai untuk lahan gambut

3. Pemupukan dan pengapuran, perlu dilakukan pemberian dolomit $500 \mathrm{~kg} /$ ha dengan pemupukan $100 \mathrm{~kg} / \mathrm{ha}$ (2 kali pemberian) dan TSP $200 \mathrm{~kg} / \mathrm{ha}$ serta $\mathrm{KCl} 125 \mathrm{~kg} / \mathrm{ha}$

4. Pembersihan kayu dan tunggul penebangan perlu dilakukan agar tidak terjadi peningkatan asam organik yang meracun dari pelapukan kayu dalam kondisi anaerob.

5. Penyiangan tanaman perlu dilakukan sampai umur tanaman 2.5 bulan minimal 2 kali penyiangan

6. Didaerah ini ada sumber air irigasi yang cukup dekat dari lahan gambut ini yaitu Sungai Pangeto.

Di Dusun Pasapuat, saat ini petani dalam kegiatan awal penanaman periode kedua. Lahan merupakan tanah gambut dengan kedalaman 1.5 meter dengan lapisan atas saprik dan lapisan bawah fibrik dan hemik. Lahan ini bersifat masam sehingga tingkat ketersediaan hara rendah. Lahan tidak memiliki drainase sehingga terlihat pada musim hujan, air tergenang dan tidak mengalir. Genangan air terlihat mengandung unsur besi yang meracun tanaman. Akibatnya pertumbuhan tanaman tidak optimal terlihat anakan sedikit. Berdasarkan laporan dari petani bahwa periode pertama hasil panen tergolong rendah, ditaksir berkisar 2-2.5 ton/Ha.

Penanaman dilakukan dengan sistem penugalan karena musim kering pada musim pertama. Akan tetapi pada penanaman kedua ini setelah musim 
hujan terlihat sebagian petani yang baru tanam dengan cara menanam bibit seperti biasanya tetapi tidak teratur (jarak tanam tidak jelas). Tanpa adanya pengolahan tanah maka lahan yang ditanam terlihat tidak bersih dari bahanbahan sisa seperti jerami bekas panen, perakaran rumput bekas ditebas. Hal ini tentunya akan menyebabkan pertumbuhan tanaman tidak sempurna karena pertumbuhan akar tanaman padi akan terhambat. Disamping itu, tanaman juga tidak diberi pemupukan dan penyiangan gulma.

\section{Kecamatan Sikakap}

Lokasi cetak sawah bukaan baru di Kecamatan Sikakap terletak di Dusun Taikako. Dusun Taikako memiliki lahan gambut yang cukup luas dan merupakan wilayah yang berpotensi untuk dikembangkan menjadi lahan sawah. Lahan Gambut di Taikako ini adalah sawah bukaan baru yang memiliki kedalaman $100 \mathrm{~s} / \mathrm{d} 150 \mathrm{~cm}$ dengan tingkat kematangan saprist setebal $10 \mathrm{~cm}$ di lapisan atas sedangkan lapisan bawahnya memiliki kematangan hemik-fibrik dan masih banyak kayu-kayu besar dan tunggul-tunggul penebangan yang masih hidup. Dilapisan tanah mineral dibawahnya didominasi oleh tekstur liat dan topografi sangat memungkinkan untuk di buat irigasi dan drainase dengan baik. Sementara ini belum ada penataan dalam hal pembuatan piring sawah dan pematang, sehingga menyebabkan ada bagian yang tergenang serta dibagian lain kering.

Di Dusun Taikako merupakan penanaman perdana dengan varietas IR 42 yang diberikan oleh dinas, tetapi varietas ini tidak tumbuh dengan baik, sehingga petani berinisiatif mengganti dengan varietas lain, namun belum merupakan varietas yang sesuai/ toleran pada gambut.

\section{Hama Dan Penyakit Tanaman Padi}

Gangguan OPT dalam budidaya sawah yang ditemukan di sawah bukaan baru di Kabupaten Kepulauan Mentawai secara umum belum merupakan masalah serius. Artinya, pada setiap lokasi permasalahan hama dan penyakit tidak menyebabkan penurunan hasil secara signifikan. Namun demikian, ada beberapa jenis serangga yang berpotensi untuk menjadi hama jika tidak dilakukan pengendalian. Berdasarkan informasi petani dan pengamatan yang dilakukan jenis walang sangit dan kepinding tanah lebih dominan sedangkan gejala serangan penggerek batang padi terlihat hanya pada satu lokasi. Sementara, penyakit tanaman padi yang dominan adalah blast dan bercak daun coklat. Berikut akan dijelaskan masing-masing jenis OPT yang ditemukan tersebut.

Walang sangit ditemukan hampir di semua lokasi yang tanamannya memasuki fase generatif. Walang sangit akan menyerang pada saat tanaman berbunga sampai membentuk bulir pada fase matang susu (Kartasapoetra,1999). Jenis ini menghisap cairan pada bulir dengan gejala serangannya berupa bercak

50 | Rafnel Azhari, dkk; Tantangan Pengembangan Padi di Kabupaten ... 
hitam pada bulir dan dapat berakibat bulir menjadi hampa. Populasi hama ini akan cepat meningkat pada saat musim kering. Dengan pengaturan waktu tanam yang tepat terutama mendapatkan fase berbunga sampai fase bulir mengeras masih dalam periode hujan akan dapat menghindari atau meminimalkan serangan hama ini. Hama ini ditemukan di Pasapuat, Taikako, Bosua, Malakopa, dan Makalo.

Kepinding tanah (hama lembing) dapat menyerang tanaman padi sejak fase vegetatif sampai generatif. Serangan pada fase awal tanaman pindah dari persemaian akan menyebabkan tanaman mengering dan mati. Tetapi jika menyerang pada fase generatif dianggap tidak akan berdampak pada kematian tanaman. Jenis ini dilaporkan oleh petani di Pasapuat cukup tinggi populasinya pada musim tanam sebelumnya. Berdasarkan laporan petani, sulit mengendalikannya dengan insektisida yang mereka peroleh dari dinas. Hal tersebut diduga karena jenis tidak tepat dan atau teknik aplikasi yang tidak tepat sasaran.

Hama penggerek batang padi ditemukan hanya di Desa Taikako tetapi populasi sangat rendah. Gejala serangannya ditemukan terjadi hampa padi dan mati per tangkai malai. Jika malai dicabut akan terlepas secara mudah. Serangan dapat terjadi pada padi dari fase vegetatif sampai generatif. Jika populasi tinggi, hama ini akan sangat menurunkan hasil dan perlu dikendalikan. Pemilihan varietas tahan merupakan salah satu cara efektif disamping penggunaan pestisida pada saat awal gejala ditemukan di pertanaman. Disamping itu, pengolahan tanah yang sempurna sebelum tanam juga efektif menekan pupa yang berada dalam tanah.

Penyakit yang dominan ditemukan adalah blast dan bercak daun. Kedua penyakit tersebut ditemukan dengan severitas sedang. Kedua jenis penyakit ini disebabkan oleh pathogen kelompok jamur (cendawan). Gejala kedua penyakit ini berbeda. Penyakit blast disebabkan oleh Pyricularia oryzae bergejala bercak coklat berbentuk belah ketupat dengan kedua ujungnya meruncing baik pada daun maupun bulir. Penyakit ini terjadi dipicu oleh tanaman yang kurang subur dengan dengan perbaikan nutrisi tanaman melalui pemupukan nitrogen dapat menghambat perkembangan gejala. Sanitasi lahan dari gulma dan jerami bekas panen juga akan menghambat perkembangan penyakit ini. Kondisi pertanaman yang tidak dilakukan penyiangan gulmaditemukan hampir di setiap lokasi. Hanya sebagian kecil petani telah melakukan penyiangan gulma pada petakan sawahnya tetapi itupun dilakukan tidak dengan sempurna. Bekas atau siangan terlihat dibiarkan berserakan di pematang yang semestinya dibuang jauh dari pertanaman atau dibenamkan. Pembenaman gulma sewaktu penyiangan dapat dilakukan jika kondisi tanah diolah tetapi pada lahan pertanaman yang tidak diolah hal tersebut tentunya dapat dilakukan. Seharusnya, penyiangan yang tepat dilakukan dengan cara membenamkan ke dalam tanah atau dibakar sebab 
pada sisa-sisa gulma yang tidak mati merupakan inang alternatif dan sumber inokulum patogen menginfeksi tanaman padi.

Penyakit bercak coklat daun disebabkan oleh Helminthosporium oryzae atau Dreschlera oryzae merupakan penyakit yang umum ditemukan pada tanaman padi yang tidak tumbuh sehat. Gejalanya berbeda dengan blast, yakni bercak pada daun berbentuk oval dan menyebar lebih merata di sepanjang daun. Faktor terjadinya penyakit ini adalah tanaman yang tidak tumbuh sehat akibat kekurangan unsur hara.

Hampir pada semua lokasi yang tergenang dengan menunjukkan gejala keracunan juga ditemukan gejala penyakit ini terutama pada daun. Oleh karena itu, pengelolaan air yakni dengan pengaliran air (drainase) yang baik dapat sekaligus menekan perkembangan penyakit ini. Disamping itu, pemberian pupuk untuk meningkatkan kesehatan tanaman sangat diperlukan.

\section{Panen Dan Pasca Panen}

Panen dilakukan oleh petani di Kabupaten Kepulauan Mentawai secara konvensional, yaitu dengan menuai. Petani menuai padi dengan memilih padi yang sudah benar-benar matang sedangkan yang dianggap kurang matang, ditinggal untuk dipanen nanti setelah dianggap matang. Dibeberapa lokasi panen dilakukan tidak secara sekaligus, sehingga panen dilakukan beberapa hari sampai selesai, bahkan pada beberapa kasus mereka tidak memanen padinya karena ada kegiatan lain.

Padi yang sudah dipanen diangkut pulang untuk dirontokkan di rumah. Kemudian padi dijemur dengan panas matahari untuk selanjutnya dilakukan penggilingan atau ditumbuk. Pada tempat yang sudah ada penggillingan atau Heller padi dapat digiling disana sedangkan yang belum ada Heller maka ditumbuk dengan lesung dari kayu.

Umumnya padi masih digunakan untuk memenuhi kebutuhan sendiri belum untuk dijual. Penjemuran atau penggilingan padi dilakukan sesuai dengan kebutuhan untuk konsumsi sendiri dan ada yang disimpan dalam bentuk gabah kering giling.

\section{Sosial Ekonomi Dan Perilaku Petani}

Secara perilaku pertanian, masyarakat Kabupaten Kepulauan Mentawai bukanlah masyarakat yang menyatu dengan budaya persawahan, hal ini disebabkan karena pada dasarnya basis pertanian mereka adalah pertanian lahan kering dengan pola perladangan. Hal ini tentu akan memberi tantangan yang besar dan tidak mudah bagi pengembangan budidaya padi di Kabupaten Kepulauan Mentawai, karena mengingat merubah perilaku petani memerlukan waktu yang cukup lama.

Hampir disemua Kecamatan lokasi penelitian, perilaku budidaya petani belum merupakan perilaku budidaya tanaman padi yang baik. Sebagai contoh, 
mayoritas petani belum terbiasa menggunakan cangkul disawah, mereka lebih senang menggunakan parang, meskipun untuk tujuan mengolah tanah. Hal ini sudah pasti menyebabkan tanah sawah mereka tidak akan terolah dengan baik. Juga hampir disemua tempat, petani tidak menyiangi gulma yang tumbuh subur dilahan sawahnya, bahkan beberapa petani responden menyatakan, bahwa meskipun gulma tumbuh subur mengalahkan tanaman padi, mereka masih akan tetap bisa membedakan mana yang padi dan yang bukan padi. Hal ini jelas menunjukkan perilaku perladangan hutan yang masih kental pada karakter mereka.

Untuk menunjang suatu persawahan diperlukan beberapa bentuk kelembagaan (Badan Litbang Pertanian, 2007), (1) kelembagaan penyedia input usaha tani, (2) Kelembagaan penyedia permodalan, (3)kelembagaan pemenuhan tenaga kerja, (4) kelembagaan penyedian lahan dan air irigasi, (5) kelembagaan usaha tani, (6) kelembagaan pengolahan hasil pertanian, (7) kelembagaan pemasaran hasil pertanian, (8) Kelembagaan penyuluhan pertanian, (9) Kelembagaan Petani/ Gapoktan. Penumbuhan dan pengembangan kelembagaan disuatu lokasi dilakukan berdasarkan prinsip kebutuhan, efisiensi dan manfaat. Kelembagaan ini harus dibentuk berdasarkan prinsip terbut, karena menjadi dasar dari keberhasilan pembukaan lahan sawah baru.

Dalam hal kasus di Kabupaten Mentawai, akan disoroti secara spesifik dari dua kelembagaan penting, yaitu: Kelembagaan penyuluhan dan kelembagaan Kelompok Tani/gapoktan.

\section{Kelembagaan Penyuluhan}

Data dari Dinas Pertanian Kabupaten Kepulauan Mentawai memperlihatkan bahwa jumlah penyuluh di Kabupaten Kepulauan Mentawai totalnya berjumlah lebih kurang 77 orang, dengan pembagian: 22 orang penyuluh PNS dan Penyuluh Kontrak 55 Orang. Jumlah tersebut masih jauh dari kondisi ideal, karena mengingat besarnya jumlah penduduk dan luas wilayah Kabupaten Kepulauan Mentawai.

Di Kabupaten Kepulauan Mentawai, juga belum terdapat Balai Penyuluhan Pertanian. Keberadaan Balai penyuluhan ini menjadi penting, agar akselerasi perubahan pengetahuan, keterampilan dan sikap petani dapat dilakukan lebih cepat dan lebih baik. Paling tidak harus telah terbangun minimal 10 Balai penyuluhan pertanian dalam waktu yang tidak terlalu lama agar dapat menjadi pusat alih teknologi dan perubahan perilaku petani khususnya petani padi pada lahan sawah bukaan baru maupun rehab.

Memperkuat kelembagaan penyuluhan pertanian menjadi penting di Kabupaten Kepulauan Mentawai baik dari sisi kuantitas dan kualitas penyuluh, termasuk juga dari sisi penyediaan anggaran yang wajar bagi kegiatan penyuluhan. Kegiatan penyuluhan pertanian dalam konteks keberhasilan budidaya tanaman padi harus didukung oleh kemampuan koordinasi yang 
bagus antar kelembagan lain. Tabel matriks koordinasi dengan kementerian atau dinas lain untuk keberhasilan kegiatan perluasan sawah:

Tabel 1 Koordinasi Antar Lembaga dalam Pengembangan Tanaman Padi

\begin{tabular}{ll}
\hline \multicolumn{1}{c}{ KOORDINASI } & \multicolumn{1}{c}{ HAMBATAN YANG DIATASI } \\
\hline Kemen PU/Dinas PU & $\begin{array}{l}\text { Penyiapan infrastruktur (bendungan/waduk, } \\
\text { saluran primer, saluran sekunder, kanal drainase } \\
\text { dan jalan) }\end{array}$ \\
Bakorluh/Dinas & $\begin{array}{l}\text { Pendampingan petani dalam mengolah sawah } \\
\text { baru } \\
\text { Pertanian }\end{array}$ \\
Kemen BUMN & $\begin{array}{l}\text { Pensuplai benih, pupuk, alsin dan sarana } \\
\text { pertanian lainnya }\end{array}$ \\
\hline
\end{tabular}

Petani adalah pelaku utama dalam kegiatan budidaya tanaman padi. Keberhasilan program ini akan sangat ditentukan oleh petani sebagai pelaku utama. Untuk itu, agar terjadi proses belajar, saling interaksi dan memudahkan koordinasi serta pengelolaan diperlukan keberadaan kelompok tani yang secara bertahap terlembagakan dengan baik.

Di lokasi pembukaan sawah baru maupun rehab, memang telah terbentuk kelompok tani. Bahkan ada beberapa kelompok tani yang anggota lebih dari seratus orang. Diantara kelompok tani tersebut adalah, kelompok tani Turak munga di dusun Pasapuat, kelompok tani Masakat Makmur di desa Saumangaya, kelompok tani Tai Bungo di Dusun Taikako dan Kelompok tani Bina Simeru di di Dusun Makalo, serta kelompok tani Siraija di Desa Malakopa.

Penguatan kelompok tani akan terkait dengan pengutan kelembagaan penyuluhan. Kelembagaan penyuluhan yang kuat akan sendirinya juga memperkuat kelembagaan kelompok tani, karena penyuluh dan petani adalah ibarat dua sisi mata uang yang saling berkaitan.

Mengupayakan perubahan perilaku petani dilakukan melalui penyuluhan. Diperlukan juga konsistensi kebijakan dalam jangka waktu yang cukup panjang, agar proses pendampingan dan fasilitasi petani sawah di Kabupaten Kepulauan mentawai terus dilakukan, karena jika program ini dihentikan dalam jangka waktu yang pendek, besar kemungkinan akan menemukan kegagalan dan petani kembali meninggalkan budidaya padi.'

\section{SIMPULAN DAN SARAN}

\section{Simpulan}

Berdasarkan hasil penelitian dapat diambil kesimpulan sebagai berikut :

1. Sebagian besar sawah bukaan baru di enam kecamatan terdiri dari lahan gambut dengan kedalaman bervariasi dari 0.4 - > 2.0 meter 
2. Sawah bukan baru yang telah dilakukan di Kabupaten Kepulauan Mentawai secara umum produktifitas masih rendah

3. Penyebab produktivitas rendah antara lain manajemen lahan, ketidaksesuaian lahan (gambut dalam), tindakan kultur teknis belum tepat termasuk pengendalian hama dan penyakit

4. Pengetahuan dan perilaku petani tentang manajemen lahan dan budidaya padi sawah belum memadai

5. Jumlah dan kualitas penyuluh pertanian masih kurang

6. Bukaan sawah baru yang telah dilaksanakan di Kabupaten Kepulauan Mentawai secara umum belum dapat diharapkan menghasilkan produktifitas maksimal disebabkan masalah kesesuaian lahan yang beragam (tidak sesuai sampai kesesuaian sedang), tanpa atau belum melakukan tindakan kultur teknis secara tepat mulai dari pegolahan lahan, pemilihan bibit, penyiangan, pemupukan dan pengelolaan air.

7. Dusun Rogdog dinilai tidak sesuai untuk dilanjutkan karena lahan berupa gambut dalam, sedangkan lokasi lainnya tergolong lahan yang dapat dimaksimalkan melalui perbaikan intensif

8. Lokasi persawahan di Madobag dan Malakopa memiliki hambatan prasarana (jalan) yang tidak memadai untuk akses petani

9. Sebagian besar petugas penyuluh sebagai ujung tombak juga belum memiliki kemampuan teknis budidaya sawah yang memadai.

\section{Saran}

Berdasarkan hasil penelitian yang telah dilakuan maka dapat diberikan saran sebagai berikut:

a. Perlu dilakukan perbaikan manajemen lahan dan teknik budidaya padi sawah terutama pembuatan saluran drainase, pemberian pupuk berimbang dan pengolahan tanah, serta pemilihan varietas yang cocok

b. Perlu dilakukan pengujian melalui demplot tentang pencarian takaran pupuk N, P dan K yang berimbang untuk semua lokasi sawah cetakan baru, karena produktivitas lahannya rendah.

c. Perlu dilakukan kajian kecocokan komoditi non padi di lahan gambut Rokdog karena lahan ini tidak sesuai secara permanen (N2) untuk tanaman padi sawah.

d. Perlu teknik pengendalian hama dan penyakit yang efektif dan ramah lingkungan

e. Perlu peningkatan pengetahuan petani dan penyuluh tentang manajemen lahan dan teknik budidaya padi sawah melalui metode sekolah lapang dengan pendampingan berkelanjutan 


\section{DAFTAR PUSTAKA}

Arsyad, S. 2010. Konservasi Tanah dan Air. Edisi Kedua. IPB Press, Bogor.

Badan Litbang Pertanian. 2007. Pengelolaan Tanaman Terpadu (PTT) Padi Sawah Irigasi. Petunjuk Teknis Lapang. Badan Litbang Pertanian, Departemen Pertanian.

Badan Pusat Statistik Kabupaten Mentawai , 2016. Produk Domestik Regional Bruto Kabupaten Kepulauan Mentawai. Kabupaten Kepulauan Mentawai : Badan Pusat Statistik.

Badan Pusat Statistik Kabupaten Mentawai , 2016. Statistik Daerah Kabupaten Kepulauan Mentawai 2016. Kabupaten Kepulauan Mentawai : Badan Pusat Statistik.

Dinas Pertanian, Peternakan dan Perkebunan Kabupaten Kepulauan Mentawai, 2015. Kerangka Acuan Kerja Fasilitasi dan Pengembangan Padi Kabupaten Kepulauan Mentawai. Kabupaten Kepulauan Mentawai. Dinas Pertanian, Peternakan dan Perkebunan.

Fahmuddin, Agus dan I.G. Made Subiksa. 2008. Lahan Gambut: Potensi untuk Pertanian dan Aspek Lingkungan. Balai Penelitian Tanah dan World Agroforestry Centre (ICRAF).

Kartasapoetra, AG. 1999. Hama tanaman pangan dan Perkebunan. Bumi Aksara, Jakarta.

Koentjaraningrat, 1985. Metode - metode Penelitian Masyarakat. Jakarta Gramedia.

Mardikanto, Totok. 2009. Sistem Penyuluhan Pertanian. Sebelas Maret University Press. Surakarta.

Nasrul, B. 2010. Penyebaran dan potensi lahan gambut di Kabupaten Bengkalis untuk pengembangan pertanian. Jurnal Agroteknologi, 1 (1):1 - 7.

Prasetyo. B.H, 2006. Evaluasi Tanah Sawah Bukaan Baru di Daerah Lubuk Linggau Sumatera Selatan. Jurnal Ilmu-Ilmu Pertanian Indonesia. 8(1): $31-43$.

Surakhmad, Winarno,1990. Pengantar Penelitian Ilmiah. Tarsito, Bandung.

56 | Rafnel Azhari, dkk; Tantangan Pengembangan Padi di Kabupaten ... 